\title{
DE AANTEEKENINGEN VAN MEINSMA OP DE BABAD TANAH DJAWI.
}

In de Bijdragen (4 $4^{\mathrm{e}}$ volgreeks, $\mathrm{l}^{\mathrm{e}}$ deel, $3 \mathrm{e}$ stuk, $2^{\mathrm{e}}$ deel, $2 \mathrm{e}$ en $3^{\mathrm{e}}$ stuk en $3^{\mathrm{e}}$ deel, $\mathrm{I}^{\mathrm{e}}$ stuk) is reeds naar aanleiding van hovengenoemde aanteekeningen gehandeld; daar de Babad zoo algemeen bij het onderwijs gebruikt wordt, komt het mij evenwel noodzakelijk voor daaraan nog de volgende aanmerkingen toe te voegen:

Bl. 5, 1 en 2 amaqmi M. zegt terecht, dat dit woord 31, 2 v. o. "denken " beteekent; dat bet. het hier ook, want de bet. volg. het Wdb. (Jav.-Ned. Handwoordenboek v. Roorda, nieuwe bewerking, Amst., Joh. Muller, 1875) "bereid " past hier niet. Bovendien heeft dit woord nog twee andere bet. die niet in het Wdb. voorkomen, nl. die van "in staat zijn", zie bl. 44, 5 v. o. en die van "begrijpen", want in plaats van het in deze Babad 42, 6 v. o. in dien zin voorkomende amman leest men in de G. B. (groote Babad in 18 deelen ter Leidsche Academische Bibliothcek) I, 284, 8 v. o. anaqmi

BI. 14, 3, teekent M. aan, dat anắanay op die plaats = mamanl aqgy is. Veilig had hij kunnen zeggen, dat het in poëzij in die bet. algemeen voorkomt.

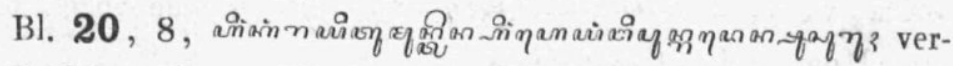
taalt M.: "de op den grootvader van Raden Soesoeroeh volgende jongere zuster" en voegt er bij : "zij was dus eene zuster van Moending Wangi enz. Volgens de Sĕdjarah eene oudere zuster "Retnå Soewidå geheeten."

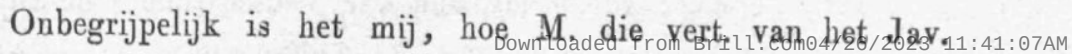


geeft; een vert., die nog wel strijdt met de opgave van de Sĕdjarah. Mijns inziens laten de Jav. woorden geene andere vert. toe dan: "haar jongere broeder vervolgens was de grootvader van Raden Soesoeroeh (Moending Wangi)" m. a. w. zij was zijn oudere zuster, en dit komt met de Sĕdjarah overeen.

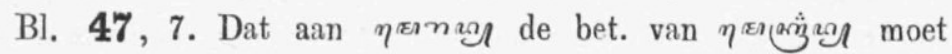
worden toegekend, zooals M. onderstelt, blijkt uit de lezing

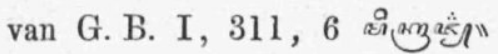

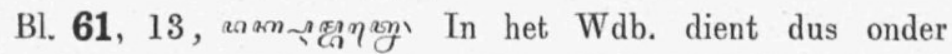

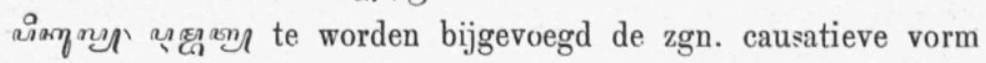
in de bet. van "op zich nemen om voor iemand iets te verrigten". Overigens verdient het gebruik v. h. Kråmåwoord ㅁㅗㅀㅛㅛ in het Ngoko en met een Ngoko aanhechtsel, opmer-

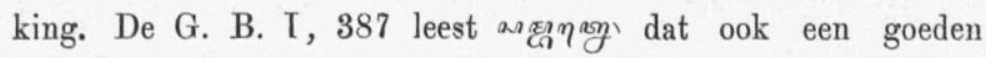
zin geeft.

Bl. 63, 11, v. о. алгамп/" M. dubieert in welke bet. dit woord hier mag voorkomen. Mij dunkt de keus is niet twijfelachtig: Djåkå Tingkir bezit wonderkracht en doodt Ki Dadoeng niet met een "haarspeld", dat is sterk, maar niet sterk genoeg. Hij doet het met een "puntig opgerold sirihblad". Ja, wat nog sterker is,

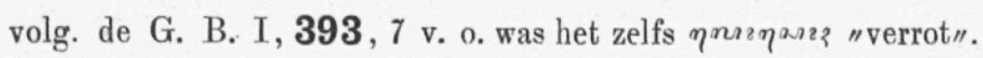

Bl. 64, 7, छngzay Dat $\varepsilon$ is zeker voorgevoegd in navolging van het poëtische E̊rya

Bl. 70, 6 v. o. In Wdb. aan te vullen amamasay z. v. a.: c⿻一𠃋十⿰纟八刀口"

Bl. 83, 2 en 1 v. o. anßiagman ook hier op te vatten in de bet. van "betrapt worden", zooals M. het terecht vert. bl. 383, 9 v. o. of in die van amazagixan (G. B. II , 15, 5, v. o. leest ๆanragiman). In deze laatste bet. komt het ook voor Bråtå

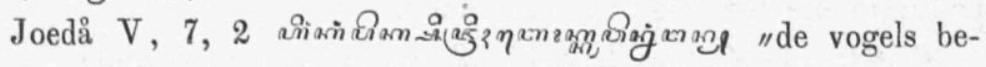
vreesd om gezien te worden."

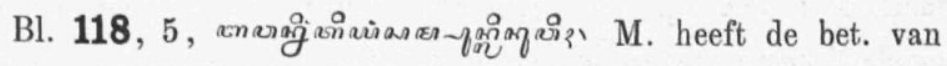

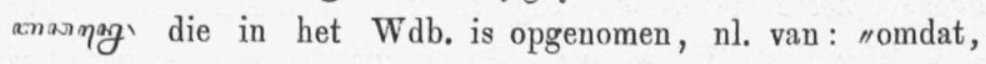
dewijl," over het hoofd gezien, en is zoo tot de weinig gelukkige vert. geraakt: "de geaardheid van mensch (onder de Bijv. 
en Verb. nog veranderd in "van den $\operatorname{man}$ ") was reeds voor. treffelijk" in plaats van: "omdat hij een voortreffeliik mensch was." Ook in het Soendaneesch bet. bawaning "omreden, omdat" ; zie Woordb. van Geerdink.

Trouwens ook andere woorden in het Jav., wier grondbeteekenis met bawa overeenkomt, worden met of zonder aanhechtsel e of ing in die redengevende bet. gebruikt. Zoo arm volg. Gericke "omdat, dewijl». In ms. 429 der Leidsche Bibl.

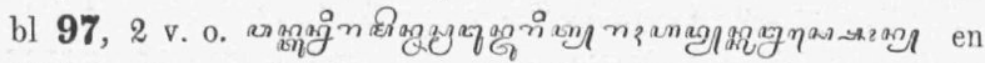
Wajang Irawan (onuitgegeven hs. door Kern beschreven Versl. en Meded. Kon. Akad. v. Wet. 1880) bl. 16, 1 v. o. es

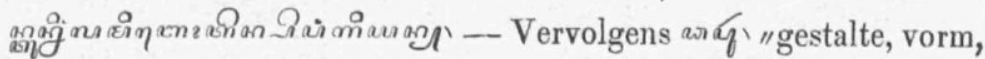
gesteldheid" ook "omrede dat, namelijk" zoo in Bandoeng (ms.

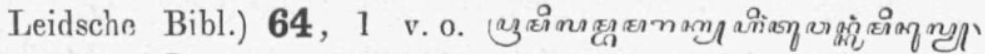

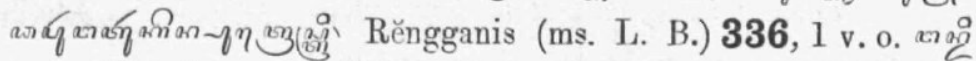

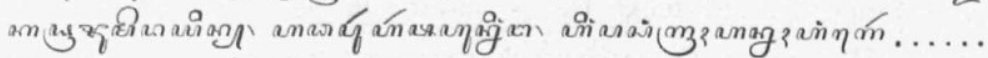

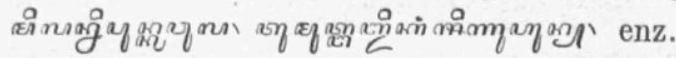

Eindelijk asás "grond, enz.; geaardheid, aard" o. a. in de

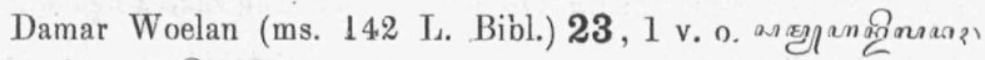

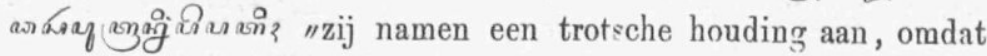
zij patih's zonen waren.

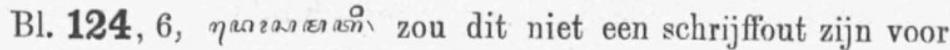

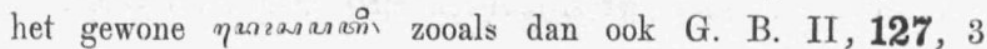
v. o. heeft.

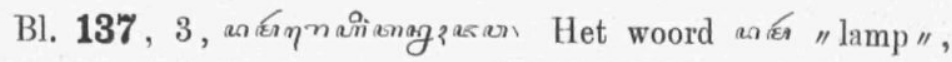
wordt dus ook figuurlijk gebruikt even als het poët. "ঞঞঞூ"

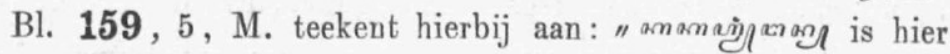
niet duidelijk; het zou moeten beteekenen "een жmă் uen", in denzelfden zin als mஸु dat zulk een woord alleenstaande in de beteekenis van een naamwoord wordt opgevat, herinner ik mij niet ontmoet te hebben. Men zal dus beter doen te lezen amamai்lanal zooals ook V. B. heeft."

Ik geef hier de woorden van M. in hun geheel terug, opdat men ze in hun verband zou kunnen beoordeelen. Zij zijn voor mij 4e Volgr. IV. 
ten eenenmale duister, en wel omdat ama் zich niet laat vergelijken met m. भुं

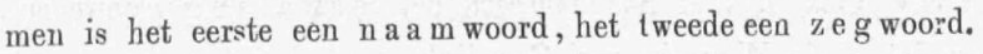

De vraag is hier m. i. deze: Vooreerst, is een vorm aman

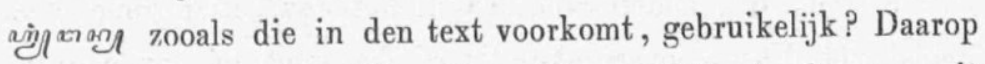
kan het antwoord veilig zijn: Neen. Wie heeft er ooit

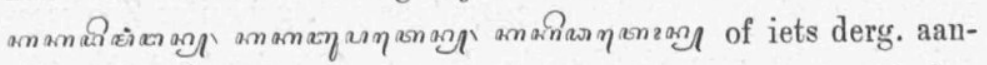
getroffen? - Maar stel al dat die vorm meer voorkwam, is dan

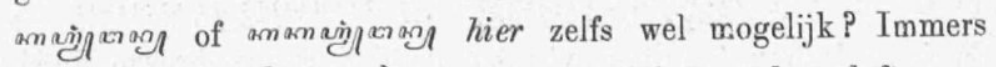

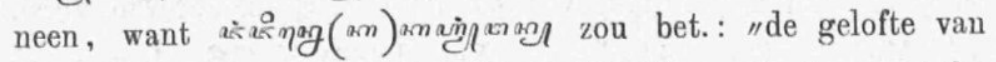
het Godenverblijf" " en dat is onzin. De eenigst mogelijke

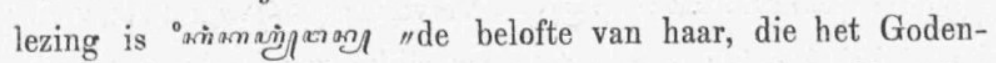
rịjk bewoont, nl. de "Ratoe Kidoel". Wij hebben hier dan ook te doen met eene nog al begrijpelijke schrijffout, nl. de weglating van het teekentje - boven de am»

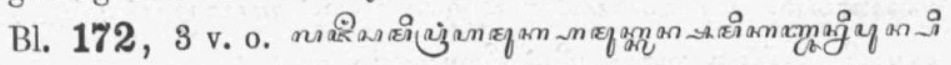

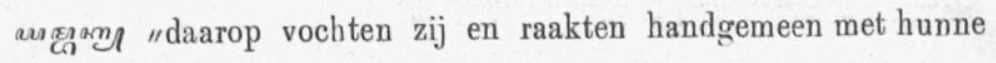
eigene (mede) kameraden." Op deze vert. zou ik niet weten wat aan te merken, maar daarop laat M. volgen : А हீ wordt klaarblijkelijk gebruikt in den zin van ons "onderling" of eene dergelijke uitdrukking als "man tegen man", en het zijn deze woorden die ik niet met stilzwijgen mag laten voorbijgaan.

Er kan hier geen sprake zijn van een lapsus calami. Anders zou men geneigd zijn te onderstellen dat M. be-

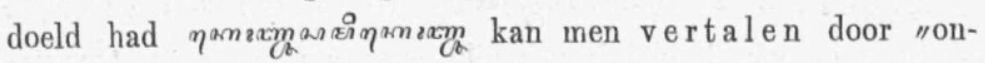
derling" of "kameraad tegen kameraad". In dat geval zou men alleen kunnen vragen, waartoe deze opmerking, daar toch de vertaling van asir hier geen bezwaar kan opleveren na kennisname van het aantal voorbeelden dat bij het woord алал алยи in het Wdb. is vertaald. Maar nu er staat, dat a का (NB. zonder meer!) wordt gebruikt in den zin van "onderling", of "man tegen man", - dat kan er niet door. Want het beteekent op die plaatsen "gelijk " of "mede-" en niets anders. Iets anders is het echter, hoe dat wrordje vert a a ld

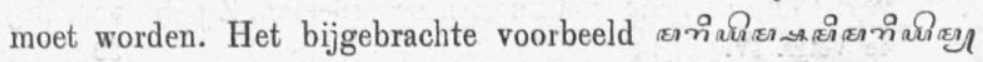


kan men best vertalen: "kanon tegen kanon". En in de Damar Woelan (ms. 142 der Leidsche Bibl.) 84, 8, waar wordt beschreven de wijze waarop de troepen met hunne verschillende

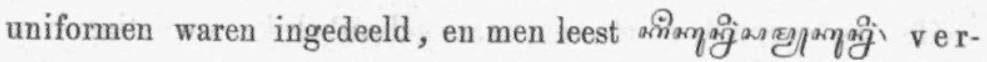
taalt men "geel bij geel". Maar daarom beteekent алю niet "tegen" of "bij". In deze en analoge voorbeelden beteekent het niets anders dan "gelijk " "mede-" of iets derg.

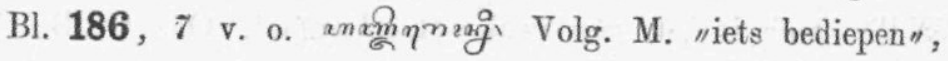
"ergens diep ingaan", "ergens iukomen". Dit is onjuist. Met

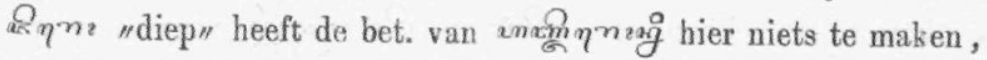
want het staat blijkens het voorafgaande asasхm as $x$ "buiten". Het is hier dan ook afgeleid van a $q \eta n$ "het binnenste" (waarvan ån̊ $\eta$ me "binnen" enz.). en wordt hier gebruikt in den zin van "ergens binnenkomen."

Bl. 256, 5, onqanan onny Over deze uitdrukking, die in de Woordenboeken niet verklaard wordt, zwijgt M. Het schijnt een vitdr. te zijn voor "in den strijd geoefend, gehard" of iets derg., - maar hoe die woorden dat kunnen bet. is niet duidelijk. Ook elders vindt men die uitdr., bv. Bandoeng (hs.

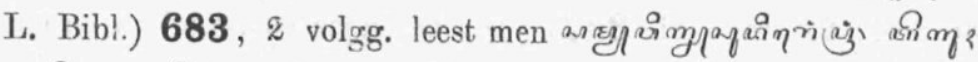

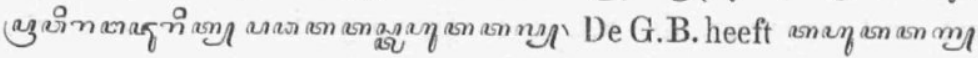
en voor dit anonml geeft het Wdb. "onverschrokken, onversaagd."

Bl. 258, 7. Met ํํำa hetgeen K. i. is van y y en

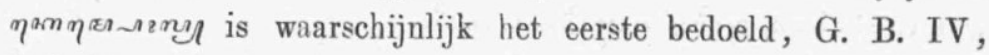
115,7 , althans heeft aq ${ }^{\prime \prime}$

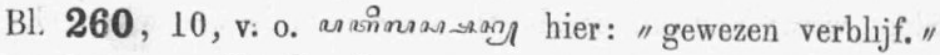

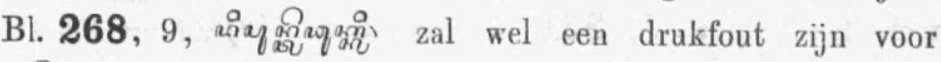

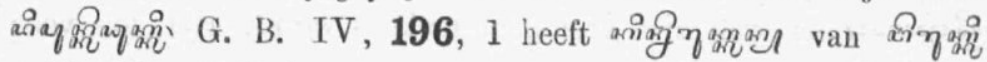
"uitkrabben, uitschrappen."

Bl. 289, 9 en 6 v. o. Met eraì "wajangpop" wordt hier bedoeld: de persoon, achter wien men zich verschuilt of door wien men handelt. G. B. IV, 280, 1 v. o. heeft ernon

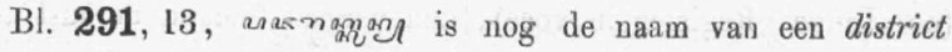
in de Residentie Pråbålinggå. 


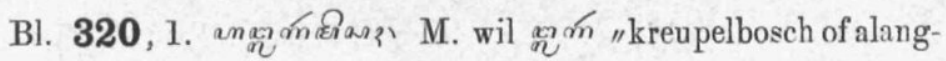
alang afbranden" hier figuurlijk laten bet. "verdelgen " of "overvallen ".

Het is evenwel (met een zeer gebruikelyke weglating van de neusletter in de voorlaatste lettergreep) niets anders dan ¿̊m een vijand aanranden.

BI. 321, 12, ๙nกmूers Het woord onnm staat niet in het Wdb.; toch is het geen druk- of schrijffout. Ook G. B. IV, 475,5 v. o. heeft het. Het schijnt in bet. wel eenige over-

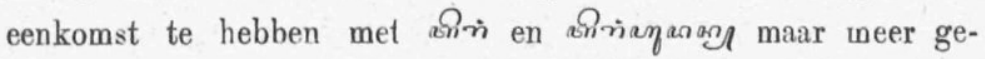
bruikt te worden van aanhoudende droogte; in de Joesoef (hs. L. Bibl.) 188, 2 v. o. komt het ten minste aldus voor: onnmagayanๆay "het was droog, er was geen regen," en dat

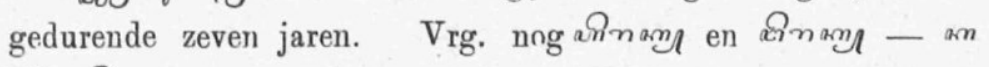
aิmณीnam oostmoesson met groote droogte.

Bl. 371, 7 v. o. xiognaryan Wat M. hiervan zegt, nl. dat met dat woord (NB. een oud Passief) "een koppel" (een naamwoord dus) zou bedoeld worden, is zoo vreemd, dat men an een lapsus calami zou gaan denken. Kern (Bijdr. 4e volgreeks, 4e deel, 2e stuk, bl. 347) vert. het door "omwonden" en dat zal wel ongeveer de bet. zijn. Ik voeg hier alleen bij, dat,

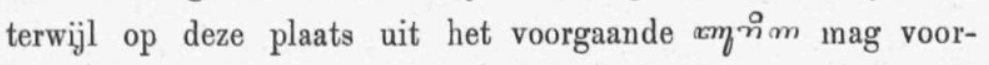
ondersteld worden, dat het van "de koppel" (de a n g ga r) wordt gezegd, deze in de G. B. V, 147, 7 v. o. bepaald genoemd

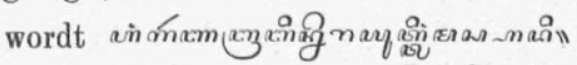

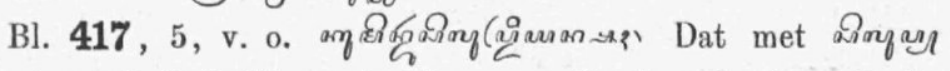
Sloot wordt bedoeld zooals M. vermoedt, is wel zeker. G. B. toch heeft hier V, 361, 5 en elders amyan - maar dat

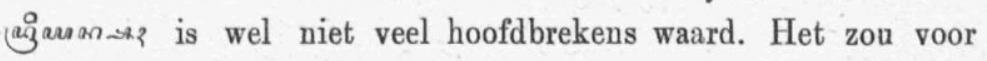
de hand liggen, om er ons "Adriaanse" in te herkennen, doch als men dan op een andere plaats VI, 113,4 leest, dat Sloot genoemd wordt qanaigman «a? "Hendrik Janse" en men daarentegen weet, dat zijn werkelijke naam was Jan Albertsz Sloot (de Jouge, Register in voce), dan vergaat iemand de lust tot verder onderzoek. 


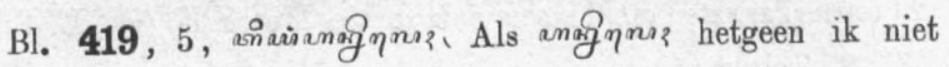
weet, bet. "pluimvee verkoopen" en dus Djiwårågå hier de zoon wordt genoemd van iemand, die zich daarmeê bezighield, dan komt dit niet overeen met de G. B. V, 418, 3 v. o. waar wij lezen, dat zịnn vader een boeroeh was ("een daglooner, huurling, koeli" of iets derg.).

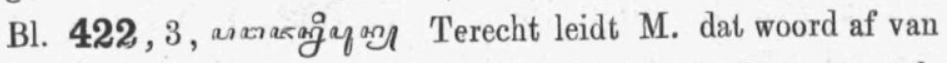
anas, waarvan crasag maar hij vergist zich in de samenstelling. Het bestaat nl. niet uit млстак 9 en añag maar uit

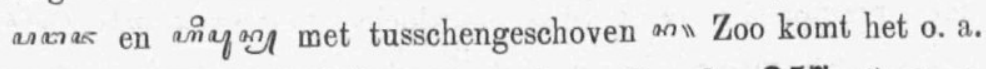
voor in Wajangverhalen uitg. door Roorda 257, 3, v. o.

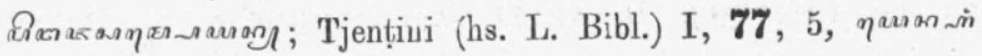

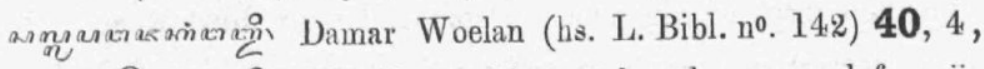

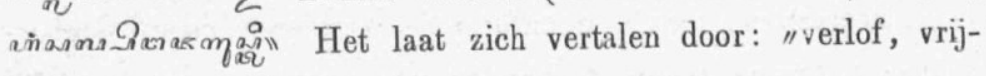
heid om iets te doen."

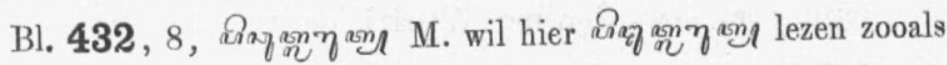
3 regels verder staat. Hij zegt, dat het klaurblijkelijk een spreekwoordelijke uitdrukking is en schijnt te bet.: de piet (of baas) "verbleekt" of zakt af (vlucht)" en een toespeling te bevatten op den Sqesoehoenan.

Ik zou de zaak juist willen omkeeren en op beide plaatseu lezen: Riagun, want in dit verhaal is nergens sprake van den Soesoehoenan, maar draait het geheele wonderstuk om de rिay "zweep". Ten gevolge van het slaan met die zweep moeten de

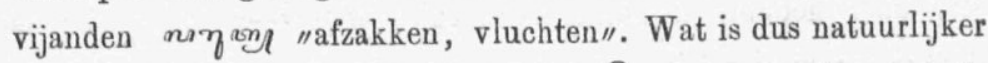

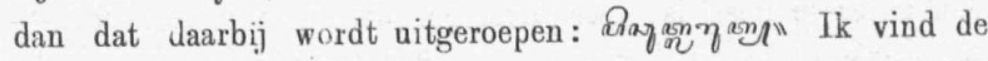
uitlegging van M. niet alleen zeer gezocht, maar meen ook,

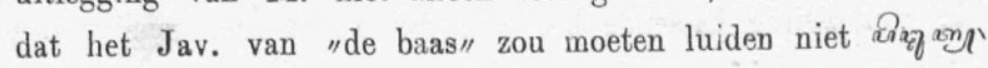

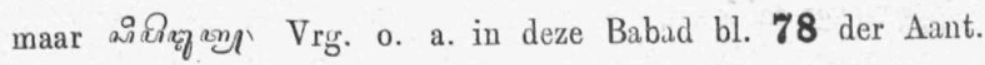
den bijnaam, die aan Soenan Mas werd gegeven "de lamme"

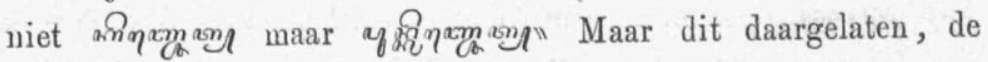
omstandigheid, dat de G. B. die deze kěmat veel uitvoeriger

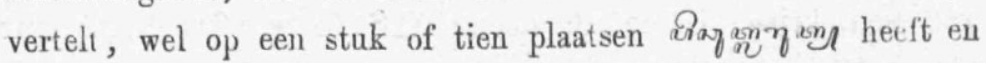

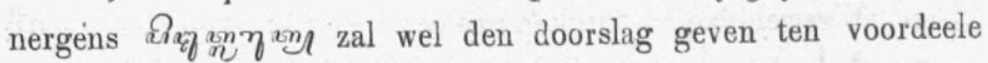
van de eerste lezing. Een voorbeeld van een derg. tooverzweep 
of tooverkarwats vindt men ook in de Moersådå (bs, L. Bibl. 77, 3, volgg.

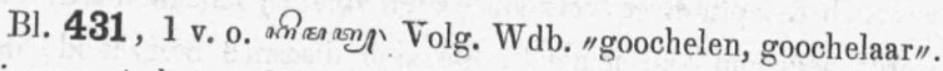
Hier moet het wel bet. "goochelarij, goocheltoer" (G. B. V, 228, gebruikt als Synoniem ascánnan "een wonderstuk") en in die of in derg. bet. komt het herhaaldelijk voor in de Ménaq (hs. L. Bibl.) zie o. a. V, 262, 4. Als de dappere Ambyah (Hamzah), de kampioen voor de Mohammedaansche godsdienst zijn ongeloovige vijanden niet op een eerlijke wijs

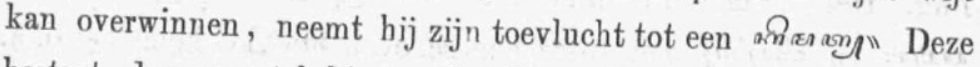
bestaat dan meestal hierin, dat hij een vervaarlijk geschreeuw

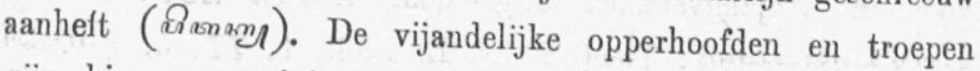
zijn hier zoo weinig tegen bestand, dat zij dikwijls als voor dood neervallen, terwijl inmiddels de Arabieren, vooraf gewaarschuwd, hunne ooren toehouden en ongedeerd blijven. Op die wijze doet ook Sijoeng Wănårå de mantri's, die worden afgezonden om hem te vatten, afdeinzen. G. B. I, 85, 1,

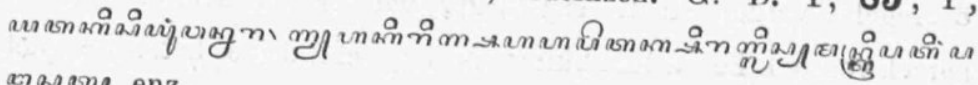
gyasang enz.

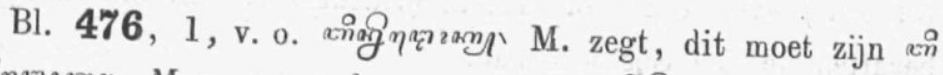

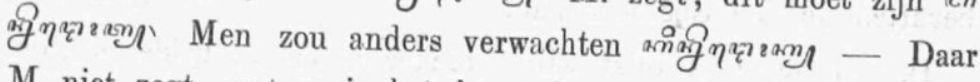
M. niet zegt, wat er in het hs. gelezen wordt, kan men voor-

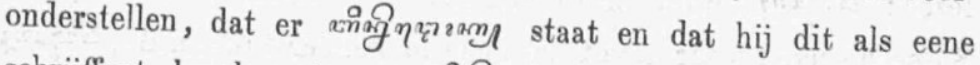

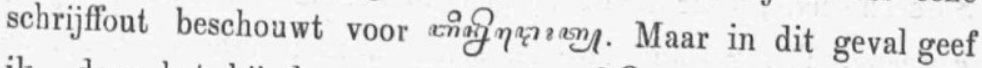

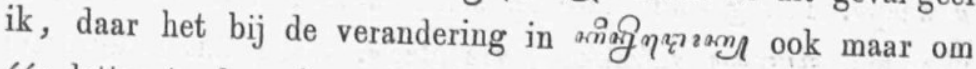
één letter te doen is, zeer zeker aan dit laatste de voorkeur. -

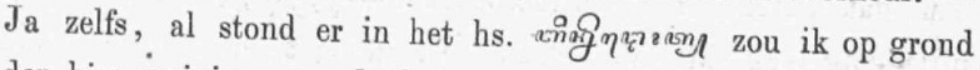
der hier weinig passende bet. van dat woord zeer geneigd zijn

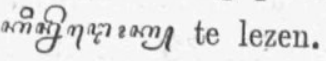

In Wdb. toch wordt op gezag van Gericke als bet. van

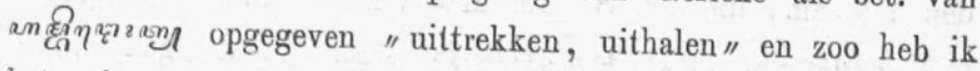
het ook gevonden in de Tjențini 318,6 voor "het uittrekken van een kris". In de Bandoeng 116, 5 wordt het gebruikt

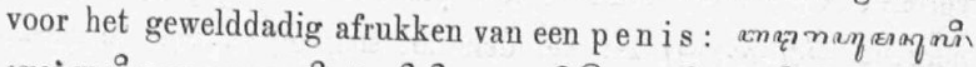

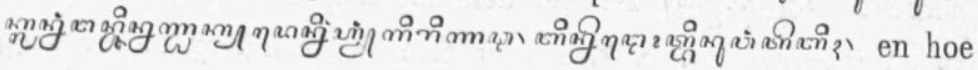


gruwelijk ook, laat zich dat denken: ja ware het nog een hoofd, de operatie zou zeker heel zwaar zijn, maar is denkbaar, doch het uittrekken, uithalen, afrukken of iets derg. van een hals schijnt absurd. Waarom dan niet gelezen

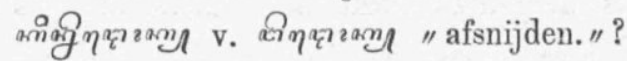

Bl. 495, 10, v. o. anainniai "otterdrek" M. schrijft hierbij : "Dit schijnt hier zeer willekeurig genomen te ziju zonder bepaalde bedoeling." Meent hij hiermeê, dat Pangeran Poegĕr niet bepaald otterdrek op het oog had, maar in het algemeen den toovenaar smadelijk wilde behandelen, dan geloof ik dat ook. G. B. ten minste heeft geheel iets anders VI, 117,

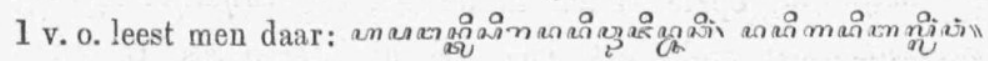

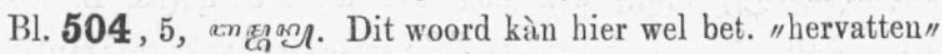
of iets derg., maar die bet. geeft Cohen Stuart in het Wdb.

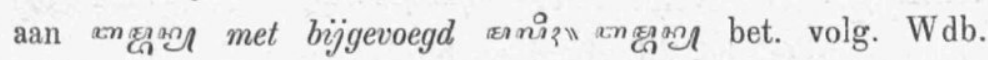
"beginnen". Deze plaats komt mij niet voor afdoende te zijn om de bet. van "hervatteu" voor кngूm zonder mis te wettigen.

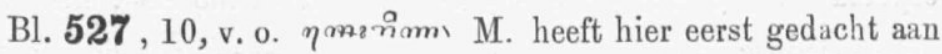
een Kawi aanhechtsel an later heeft hij deze onwaarschijnlijke conjectuur teruggenomen - en zegt eenvoudig, dat het niets meer

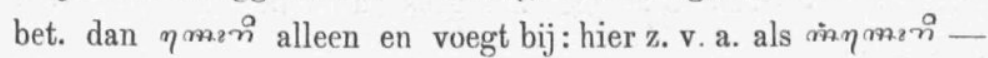
Blijkbaar weet hij dus geen weg met die $m$ । - Zou het niet

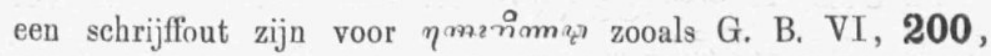
3 , v. o. heeft?

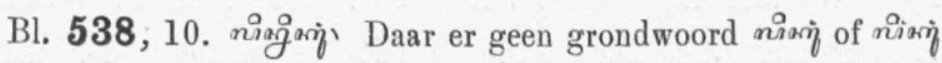
in de Woordenboeken voorkomt, wil M. lezen nimgin' dat zou bet. "gepasseerd zijn, voorbijgeraakt zijn". Zoo zou de zin in zijn geheel luiden: de Patih Soemå bråtå ziende, dat zijn troepen gepasseerd of voorbijgeraakt waren - ging op de vlucht. Ik moet bekennen dat ik dit niet versta, maar nog minder een ninjàj "gepasseerd, voorbijgeraakt zijn" als conjectuur voor

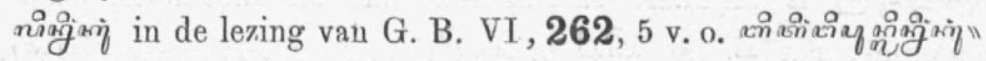

Daar trouwens zoowel de Babad van M. als de G. B. niagini of niagini hebben, schijnt er wel degelijk een derg. vorm 
van een grondwoord nisin of nixi te bestaan, al is die ons ook onbekend. Mij komt het ook niet onwaarschijnlijk voor, dat er meê kan bedoeld zijn : "in een cirkel ingesloten worden, omsingeld worden." Iets dergelijks heeft er immers blijkens het voorafgaande $\sin x$ hier plats, en zulk een bet. zou wel overeen te brengen zijn met andere Jav. woorden, waar ai

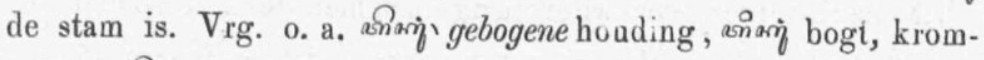

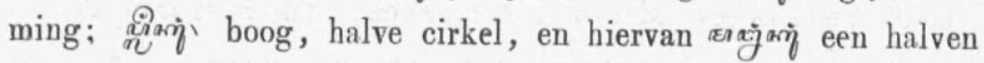
cirkel vormen.

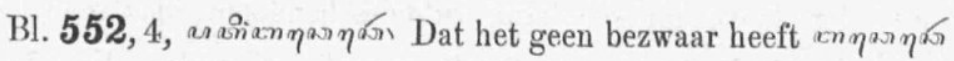

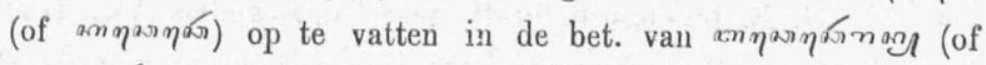

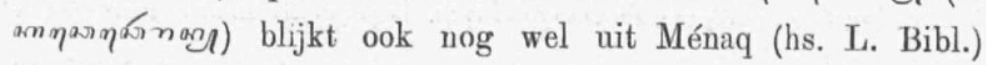

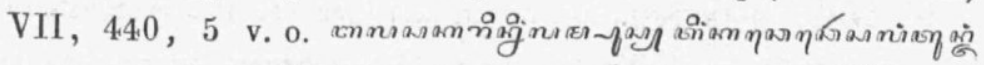

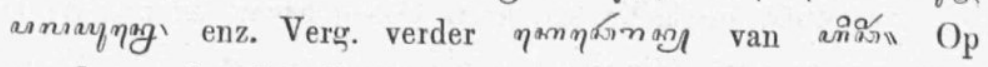
grond van het bij dit woord en bij het door $M$. aangehaalde ลำง in Wdb. opgegevene, zal aan кn de bet. wel moeten worden toegekend van "zoek rakeu, meer bepaald v. gedeelten, die bij iets anders behooren"; hier van enkele manschappen of troepen die achterbleven, van den hoofdtroep verwijderd en zoo zoek raakten, omdat zij den haastigen gang van Soenan Mas met het gros van zijn leger niet konden volgen.

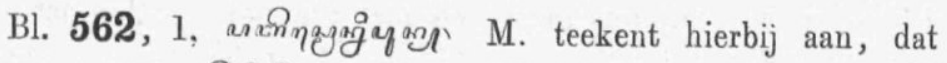

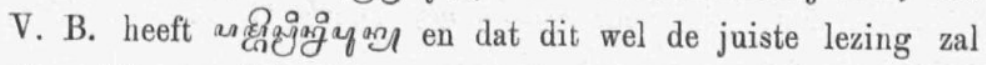
zijn. Waarom hij dit opmerkt, begrijp ik niet. De verwaarloozing toch van den neusletter vóór de zachte medeklinker, is waarlijk niet vreemd, (Vrg. o. a. in deze Babaả 370, 4 v. o.

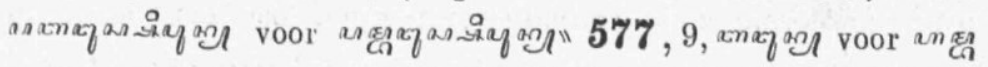
শ๐an - of wil men een voorbeeld elders: Pandjī Koedånårå-

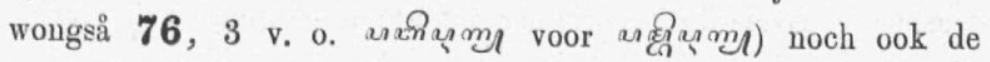

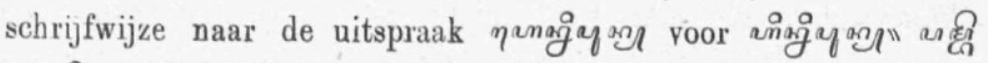

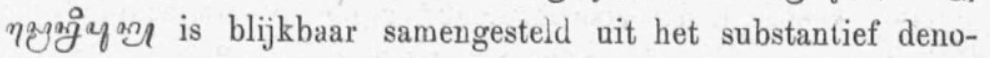

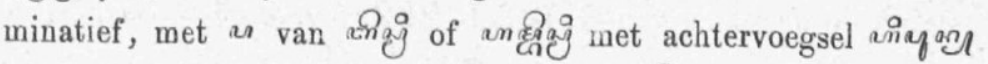

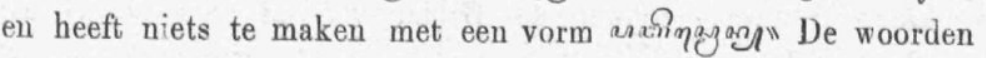

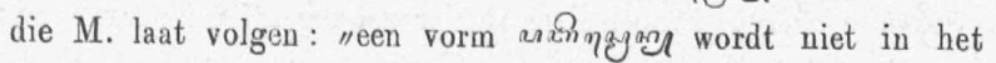


Wdb. opgegeven" kunnen dan ook alleen tot verwarring leiden.

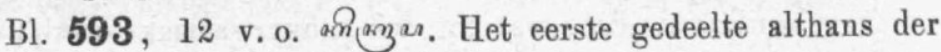
door Roorda opgegeven bet. wordt bevestigd door de omschrijving

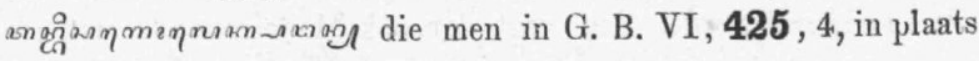

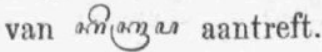

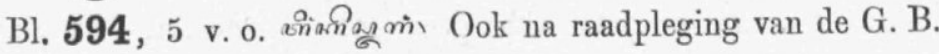
kan $\mathrm{ik}$ de beteekenis dezer woorden niet helpen bepalen, maar

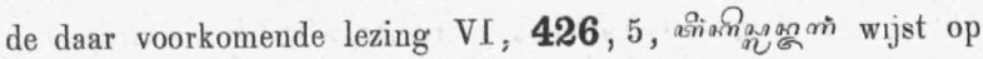
twee zaken.

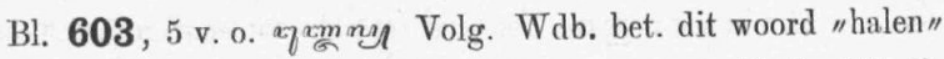
o. a. vogels die bouwstoffen halen voor hun nest. M. breidt die bet. uit en zegt: van daar "zich gaan nestelen"; hier wil hij het fig. laten beteekenen : van den Pangeran "zich gaan nestelen aan boord". Ik durf mij aan deze zeer gezochte en alleen op gissing steunende verklaring niet wagen, te minder, omdat de grondbet. van het woord nl. "halen" eenigszins ruimer genomen een veel beteren zin geeft. Met het voorafgaande luidt het dan:

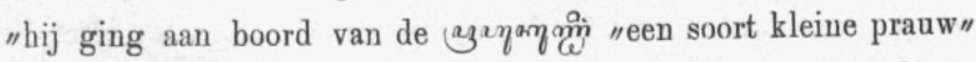
die hem haalde of afhaalde om hem te brengen naar boord van het groote schip.

Bl. 604, 10 v. o. qaszinzang De G. B. leert ons, dat wij hier te doen hebben met iets dat bij een geweer behoort.

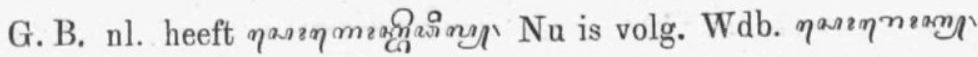

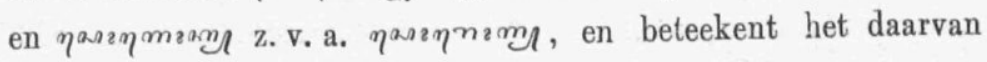

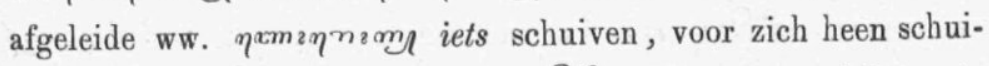
ven. Met het in de G. B. volg. ฉhainn "geweer" schijnt er te worden bedoeld: het werktuig, dat den kogel in den loop van het geweer schuift, voortschuift- m.a. w.: de laadstok.

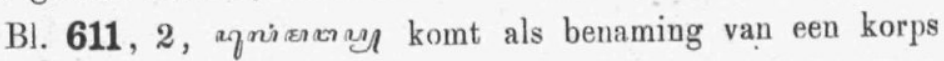
soldaten ook voor o. à. in de Damar Woelan (hs. 142 L. Bibl.) 63,2 v. o.

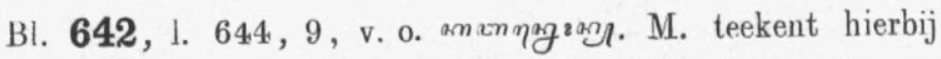
aan: letterlijk "tot een muur gemaakt worden", doch hier is

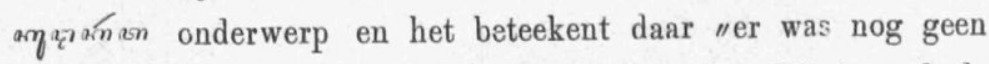
muur gemaakt, het was nog niet ommuurd." Dit is gedeel- 
telijk waar, gedeeltelijk niet. De eerste bet. is juist, maar wordt gebruikt van dat, wat tot een muur gemakt wordt, en kan ons dus hier niet helpen, daar er sprake is van de plaats, die ommuurd wordt. Zoo zegt dan ook M. terecht: Koețakĕrta is onderwerp, maar hoe kan hij er dan op laten volgen, dat het bet. zou: er was nog geen muur gemaakt. De plaats Koețakerta en muur kunnen toch niet tegelijk onderwerp zijn? Dit laatste bet. het dan ook niet, maar wel het daarop volgende: "het was nog niet ommuurd" en dit hebben we hier noodig. Het ww. an gूom bet. dus zoowel "tot een muur maken" als "ommuren" twee bet. die moeielijk overeen te brengen zijn. Toch laat zich de bet. van "ommuren" zeer goed verklaren. cnqay ran nl. "baksteen" in de bet. van "muur" is eigenlijk

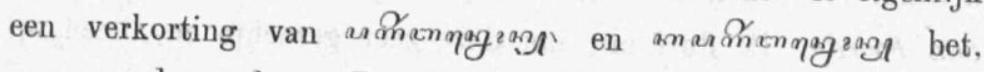

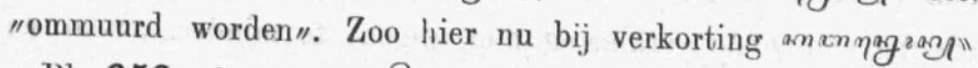
B1. 650,3 v. o. asmasias amy Of deze vorm meer voorkomt in den zin van "plaats waar of degeen bij wien men moet verschijnen om dienst te doen", zooals M. opgeeft, weet ik niet; het komt niet in het $\mathrm{Wdb}$. voor evenmin als мxхіณи пая zooals de V. B. leest en M. vertaalt "degeen dien men als zijn hoofd erkent ". Maar daar dit laatste meer voorkomt, o. a. in Bajan Boediman (hs. L. Bibl.) waar de patih namens zijne 100 makkers (bajan's, een soort perkieten?) de vorstelijke waardigheid aan den Bajan Boediman aanbiedt, en o. a. zegt:

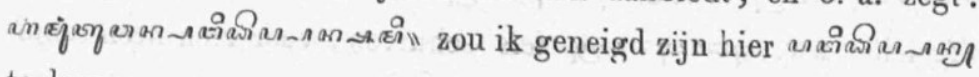
te lezen.

A. C. VReede. 